\title{
Comparison of Growth Hormone and Insulin-Like Growth Factor-I Regulation of Estradiol and Progesterone Production in Human Luteinized Granulosa Cells
}

\author{
CAROL M. FOSTER, NOBUKO HASHIMOTO,${ }^{1}$ JOHN F. RANDOLPH, JR., AND INESE Z. BEITINS \\ Departments of Pediatrics [C.M.F., N.H., I.Z.B.] and Obstetrics and Gynecology [J.R.], University of \\ Michigan School of Medicine, Ann Arbor, Michigan 48109
}

\section{ABSTRACT}

\begin{abstract}
Growth hormone $(\mathrm{GH})$ appears to affect the timing of puberty in children. The effects of GH on puberty may be related to direct $\mathrm{GH}$ action on ovarian function or may be mediated by IGF-I. To determine the likelihood that GH has direct effects on ovarian function, we compared the ability of GH and IGF-I to increase luteinized granulosa cell steroidogenesis in the absence and presence of gonadotropins. Cells were obtained from women undergoing in vitro fertilization for tubal disorders or male factor infertility and were placed in static culture. GH alone failed to alter progesterone or estradiol accumulation in the medium of cultured luteinized granulosa cells. IGF-I produced no increase in progesterone accumulation but increased estradiol accumulation 5.6-fold compared with cells treated with vehicle. The combina-
\end{abstract}

tion of $\mathrm{GH}$ and FSH produced an 0.83 -fold increase in estradiol accumulation, whereas the combination of IGF-I and FSH resulted in a 2.9-fold increase in estradiol accumulation above FSH alone. Thus the direct effects of GH on granulosa cell steroid synthesis are modest compared with those of IGF-I. If GH has an effect on ovarian development at puberty, it is likely to be mediated by a GH-induced increase in circulating IGF-I. (Pediatr Res 38: 763-767, 1995)

Abbreviations
GH, growth hormone
IGFBP-3, insulin-like growth factor binding protein-3

$\mathrm{GH}$ is thought to play a role in the timing of the onset of puberty. GH-deficient children have delayed adolescent development, and the timing of their puberty can be accelerated by administration of exogenous GH (1). Exogenous GH has also been found to augment the ability of administered FSH to induce follicular development in women with hypopituitarism and in women undergoing in vitro fertilization procedures (2-5). The ability of GH to augment gonadotropin action in the ovary may be related to an increase in IGF-I which is produced in response to exogenous GH (6). IGF-I has been shown to augment gonadotropin stimulation of steroidogenesis in human granulosa cells (7). GH, however, may be able to stimulate ovarian development or steroidogenesis directly, because $\mathrm{GH}$ receptors have been demonstrated in the human ovary (8), and, in animal studies, GH treatment increases steroidogenesis and gonadotropin receptor development $(9,10)$.

Received Novcmber 11, 1994; accepted June 6, 1995.

Correspondence: Carol M. Foster, M.D., Department of Pediatrics/Endocrinology, D3252 MPB Box 0718, University of Michigan Medical School, Ann Arbor, MI 48109.

Supported by the National Cooperative Program for Infertility Research through the National Center for Infertility Research at Michigan (U.S. Public Health Service Grant HD-29184).

${ }^{1}$ Current address: Department of Pediatrics, Odaira Memorial Tokyo Hitachi Hospital, 3-5-7 Yushima, Bunkyo-Ku, Tokyo 113, Japan.
To better understand how GH may affect ovarian development, we compared the ability of GH and IGF-I to increase steroidogenesis in luteinized human granulosa cells obtained from women undergoing in vitro fertilization procedures. We tested the hypothesis that GH, like IGF-I, would directly stimulate estradiol and progesterone production in luteinized granulosa cells maintained in static culture.

\section{METHODS}

Subjects. Luteinized ovarian granulosa cells were obtained during oocyte retrieval from women undergoing in vitro fertilization procedures for either tubal disorders or male factor infertility. Oral consent for use of the cells was obtained from each woman, and the consent procedure and protocols were approved by the Institutional Review Board of the University of Michigan. All received treatment with a gonadotropinreleasing hormone agonist for suppression of endogenous gonadotropins, human menopausal gonadotropins, and human chorionic gonadotropin administered 35 h before oocyte retrieval.

Materials. Medium preparations, antibiotics, L-glutamine, and FCS were purchased from either Irvine (Santa Ana, CA) or 
Life Technologies, Inc., Grand Island, NY). Epidermal growth factor, thyroxin, hydrocortisone, transferrin, retinol acetate, methylisobutylxanthine, and androstenedione were purchased from Sigma Chemical Co. (St. Louis, MO). BSA (CRG-7) was from Armor (Kankakee, IL). Human recombinant-DNAderived 22,000-D GH and human recombinant DNA-derivedIGF-I were a gift from Lilly Research Laboratories (Indianapolis, IN). LH (WHO 78-549) and FSH (I-3) were obtained from the National Hormone and Pituitary Program, National Institute of Diabetes and Digestive and Kidney Diseases (Rockville, MD).

Cell culture. Cells received after oocyte retrieval were centrifuged from follicular fluid at $100 \times g$. The cells were suspended in Ham's F-10 medium, layered over FicollHypaque (Pharmacia Biotech Inc., Piscataway, NJ), and centrifuged for $15 \mathrm{~min}$ at $100 \times \mathrm{g}$. The layer at the medium-Ficoll interface was removed, washed three times in Ham's F-10 medium, and suspended in Ham's F-10 medium containing $10 \% \mathrm{FCS}$ and $20 \mathrm{ng} / \mathrm{mL}$ gentamicin except as noted. The number of granulosa cells present was estimated using a hemocytometer, and greater than $95 \%$ of the cells were viable by trypan blue dye exclusion. As an additional test of viability, statistically significant stimulation of progesterone by $\mathrm{LH}$ or estradiol by FSH was required in each experiment, before overall results were accepted. Cell suspensions were adjusted to allow plating at a density of 200,000 cells per well in Corning 24-well plates. Cells were allowed to attach for at least $24 \mathrm{~h}$. Except where indicated, the medium for experiments where progesterone was measured was Ham's F-10 medium containing $0.5 \mu \mathrm{M}$ cholesterol. The medium for estradiol measurements was a modification of the Sertoli cell medium described by Padmanabhan et al. (11) consisting of a 1:1 mixture of Ham's F-10 and Dulbecco's modified Eagle's medium, $0.1 \% \mathrm{BSA}, 20 \mu \mathrm{g} / \mathrm{mL}$ thyroxine, $10 \mathrm{nM}$ hydrocortisone, $10 \mathrm{ng} / \mathrm{mL}$ epidermal growth factor, $0.1 \mathrm{mM}$ methylisobutylxanthine, $10 \mu \mathrm{M}$ retinol acetate, $5 \mu \mathrm{g} / \mathrm{L}$ transferrin, $20 \mathrm{ng} / \mathrm{mL}$ gentamicin, $1 \mathrm{ng} / \mathrm{mL}$ Fungizone, and $2.5 \mu \mathrm{M}$ androstenedione.

Hormone assays. Progesterone was determined by double antibody RIA using kits purchased from ICN (Costa Mesa, $\mathrm{CA}$ ) or Inkstar (Stillwater, MN) The assay sensitivity was 0.6 $\mathrm{nM}$, and the intra- and interassay coefficients of variation were 8.6 and $14.6 \%$, respectively. Estradiol was determined by RIA, using charcoal to separate bound from free hormone, as described previously (12). The assay sensitivity averaged 92 $\mathrm{pmol} / \mathrm{L}$ and the intra- and interassay coefficients of variation were 9.7 and $18.4 \%$, respectively. Estradiol was iodinated by the Assay Development Core of the Reproductive Sciences Program of the University of Michigan.

Statistics. For each treatment well, estradiol or progesterone concentrations were determined twice and averaged. The values for each treatment or hormone concentration in an individual experiment represents the mean \pm SE of four separate wells of cells. Each well was treated with $1 \mathrm{~mL}$ of medium so that results expressed per $\mathrm{mL}$ also represent steroid production per 200,000 cells. All data underwent logarithmic transformation before analysis. Analyses were by one-way repeated measures analysis of variance or factorial analysis of variance as appropriate. A $P$ value of $<0.05$ was considered significant.
Results shown are for individual experiments. Each experiment was repeated at least once to confirm the reproducibility of the findings.

\section{RESULTS}

Absence of GH effect on progesterone production. Cells incubated for 24 or $48 \mathrm{~h}$ in medium containing $10 \% \mathrm{FCS}, 24 \mathrm{~h}$ of serum-free medium, and $24 \mathrm{~h}$ with 0.1 to $1000 \mathrm{ng} / \mathrm{mL} \mathrm{LH}$ exhibited a maximum dose response of $100 \mathrm{ng} / \mathrm{mL}$ (data not shown). Subsequent experiments were conducted with 100 $\mathrm{ng} / \mathrm{mL}$ LH. The time course of incubation required to maximize progesterone release into the medium was determined by preincubating luteinized granulosa cells for 24-120 h in Ham's F-10 medium containing $10 \%$ FCS followed by an additional $24 \mathrm{~h}$ in serum-free Ham's F-10 medium containing $0.1 \%$ BSA and $0.5 \mu \mathrm{M}$ cholesterol. Cells were then treated for $24 \mathrm{~h}$ with vehicle, $100 \mathrm{ng} / \mathrm{mL} \mathrm{LH}, 500 \mu \mathrm{g} / \mathrm{L} \mathrm{GH}$, or a combination of $\mathrm{LH}$ and GH. After $24 \mathrm{~h}$, the medium was removed and assayed for progesterone. The results of one representative experiment are shown in Figure 1. After $48 \mathrm{~h}$ of preincubation in medium containing serum, the LH-stimulated progesterone accumulation in the medium was significantly greater than that seen in cells treated with vehicle. In the experiment shown in Figure 1, $500 \mu \mathrm{g} / \mathrm{L}$ GH did not stimulate progesterone accumulation above control values either alone or in the presence of $\mathrm{LH}$, at any time point. In a series of experiments, cells were incubated for $24-120 \mathrm{~h}$ in medium containing serum followed by a $24-\mathrm{h}$ incubation in serum-free medium containing $0.1 \%$ BSA and $0.5 \mu \mathrm{M}$ cholesterol. The cells were treated with GH in concentrations ranging from 0.1 to $1000 \mu \mathrm{g} / \mathrm{L}$ for an additional 24 , 48 , or $72 \mathrm{~h}$. In no case did GH increase progesterone synthesis above that seen in cells treated with a control vehicle. A typical experiment demonstrating the lack of a $\mathrm{GH}$ dose response on

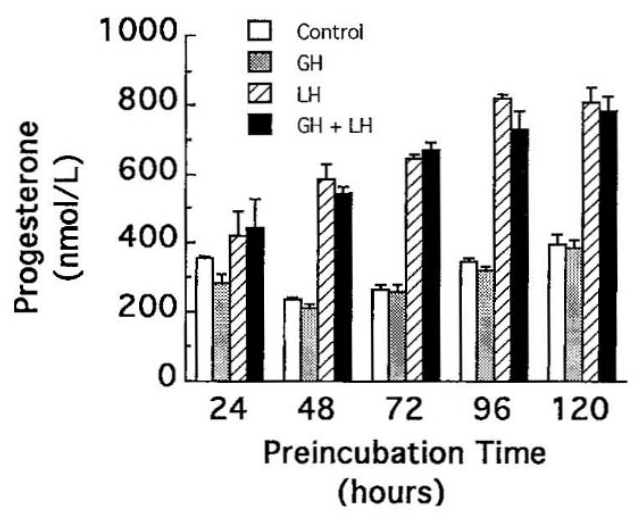

Figure 1. Effect of time in culture on response to GH and LH stimulation of progesterone production. Cells were maintained in culture with Ham's F-10 medium containing $10 \%$ FCS for the indicated times. The medium was replaced with serum-free medium for $24 \mathrm{~h}$ and then replaced with medium containing a control vehicle, $500 \mu \mathrm{g} / \mathrm{L} \mathrm{GH}, 100 \mathrm{ng} / \mathrm{mL} \mathrm{LH}$, or a combination of $500 \mu \mathrm{g} / \mathrm{L} \mathrm{GH}$ and $100 \mathrm{ng} / \mathrm{mL} \mathrm{LH}$. After $24 \mathrm{~h}$ of hormone exposure, the medium was removed and the progesterone content determined. Each bar is the mean \pm SE of four determinations. Each well contained 200,000 cells and 1 $\mathrm{mL}$ of medium. Cells treated with $\mathrm{LH}$ or $\mathrm{LH}$ and $\mathrm{GH}$ had significantly more progesterone $(p<0.01)$ than control cells at $48,72,96$, and $120 \mathrm{~h}$ of preincubation with serum. There were no differences in progesterone production between cells treated with control or with $\mathrm{GH}$ and between cells treated with $\mathrm{LH}$ and $\mathrm{LH}+\mathrm{GH}$. This experiment was replicated three times. 
progesterone accumulation is shown in Figure 2. In the experiment shown, 200,000 cells/well were preincubated for $48 \mathrm{~h}$ with Ham's F-10 medium containing $10 \%$ FCS. After a $24-\mathrm{h}$ incubation in serum-free medium, hormones were added for an additional $24 \mathrm{~h}$.

Also shown in Figure 2 are the effects of $100 \mathrm{ng} / \mathrm{mL}$ IGF-I on progesterone accumulation with and without GH. IGF-I alone did not increase progesterone accumulation. $\mathrm{GH}$ and IGF-I in combination were no more effective than either hormone alone. LH, $100 \mathrm{ng} / \mathrm{mL}$, stimulated progesterone accumulation, and its effect was not augmented by GH. IGF-I has been tested in concentrations ranging from 0.5 to $500 \mathrm{ng} / \mathrm{mL}$ without evidence of consistent stimulation of progesterone accumulation (data not shown). The combination of 50 or $500 \mu \mathrm{g} / \mathrm{L} \mathrm{GH}$ with submaximal stimulatory concentrations of $\mathrm{LH}(0.1-10$ $\mathrm{ng} / \mathrm{mL}$ ) also failed to further augment $\mathrm{LH}$ stimulation of progesterone accumulation (data not shown).

GH effects on estradiol production. The medium of cells treated with Ham's F-10 medium and $0.5 \mu \mathrm{M}$ cholesterol in cells subjected to conditions described above failed to demonstrate measurable estradiol. Medium 199, Ham's F-10 medium containing $2.5 \mu \mathrm{M}$ androstenedione, and McCoy's medium also either failed to improve the ability to measure estradiol or lacked evidence of gonadotropin stimulation of estradiol accumulation (data not shown). Therefore, cells were incubated using a modification of the Sertoli cell medium described by Padmanabhan et al. (11), where insulin was omitted from the medium formulation to allow detection of IGF-I effects. Cells were maintained in Sertoli cell medium containing $10 \%$ FCS for up to $8 \mathrm{~d}$. Before addition of hormones, medium was replaced with serum-free Sertoli cell medium for $24 \mathrm{~h}$. The serum-free medium was replaced with Sertoli cell medium containing vehicle or $10 \mathrm{ng} / \mathrm{mL} \mathrm{FSH}$, and after an additional 24 $\mathrm{h}$ the medium was removed and assayed for estradiol. Stimulation of estradiol accumulation by FSH was seen for cells maintained for up to $5 \mathrm{~d}$ in medium containing serum. After 6 $\mathrm{d}$ with serum, or $8 \mathrm{~d}$ of total culture, there was no longer $\mathrm{FSH}$

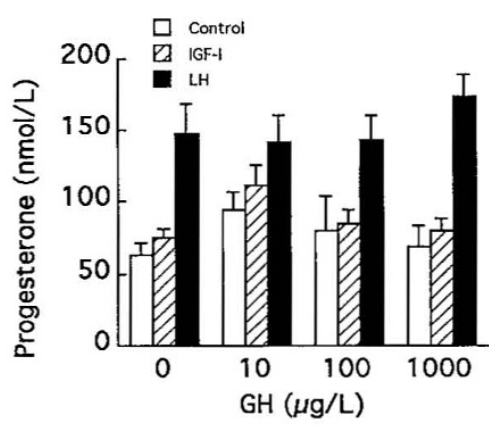

Figure 2. Effect of GH and IGF-I on progesterone production. Cells were incubated for $3 \mathrm{~d}$ with Ham's F-10 medium, $24 \mathrm{~h}$ with serum-free medium, and $24 \mathrm{~h}$ with control vehicle, $100 \mathrm{ng} / \mathrm{mL} \mathrm{IGF-I,} \mathrm{or} 100 \mathrm{ng} / \mathrm{mL} \mathrm{LH}$ and the indicated concentration of GH. After $24 \mathrm{~h}$, the medium was removed and assayed for progesterone concentration. Although LH stimulated progesterone production compared with control cells at each $\mathrm{GH}$ concentration tested $(p<$ $0.05)$, the presence of any concentration of GH did not enhance LH-stimulated progesterone production. IGF-I did not increase progesterone production in the absence or presence of $\mathrm{GH}$. Each bar is the mean $\pm \mathrm{SE}$ of four determinations. Each well contained 200,000 cells and $1 \mathrm{~mL}$ of medium. This experiment was replicated once. stimulation of estradiol accumulation compared with cells treated with vehicle (data not shown). Additionally, the maximum sensitivity of the cells to FSH was determined by incubation with FSH at concentrations of 0.01 to $100 \mathrm{ng} / \mathrm{mL}$ The peak estradiol accumulation occurred between 10 and 100 $\mathrm{ng} / \mathrm{mL}$ FSH (data not shown). Subsequent experiments were performed with $10 \mathrm{ng} / \mathrm{mL}$ FSH. Addition of GH at concentrations of $0.1-1000 \mu \mathrm{g} / \mathrm{L}$ did not increase estradiol accumulation in the medium under any condition of incubation (data not shown).

To determine whether GH or FSH might maintain the ability of cells to produce estradiol, cells were first incubated for $24 \mathrm{~h}$ in Ham's F-10 medium containing 10\% FCS and then placed in serum-free Sertoli cell medium containing a control vehicle, $500 \mu \mathrm{g} / \mathrm{L} \mathrm{GH}, 100 \mathrm{ng} / \mathrm{mL} \mathrm{LH}, 10 \mathrm{ng} / \mathrm{mL}$ FSH, or combinations of $\mathrm{GH}$ and $\mathrm{LH}$ or FSH. The medium was then removed daily and replaced by fresh Sertoli cell medium containing the same hormones for up to $120 \mathrm{~h}$. Estradiol was measured in the medium collected each day. As shown in Figure 3, estradiol was readily detected in the medium after the first $24 \mathrm{~h}$ of incubation in Sertoli cell serum-free medium. However, the stimulation of estradiol accumulation in the medium by 100
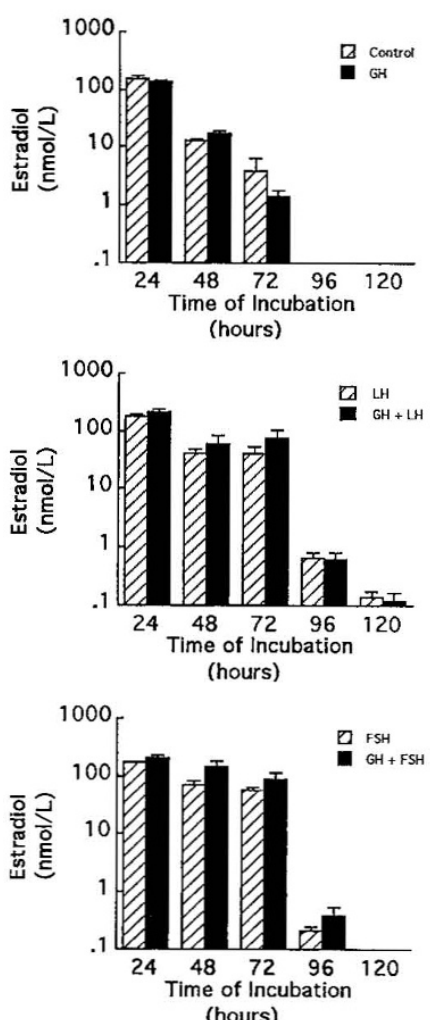

Figure 3. Effect of GH, FSH, and $\mathrm{LH}$ on estradiol production. Cells were maintained for $24 \mathrm{~h}$ with Ham's F-10 medium containing $10 \%$ FCS. The medium was replaced with serum-free Sertoli cell medium containing control vehicle, $500 \mu \mathrm{g} / \mathrm{L} \mathrm{GH}, 100 \mathrm{ng} / \mathrm{mL} \mathrm{LH}, 10 \mathrm{ng} / \mathrm{mL}$ FSH, or a combination of $\mathrm{LH}$ and $\mathrm{GH}$ or FSH and GH. Medium was collected at the end of each $24 \mathrm{~h}$ period for $120 \mathrm{~h}$ and replaced with fresh medium containing the same hormones. Estradiol concentration was determined in the medium collected each day. At $48 \mathrm{~h}$, cells treated with GH and FSH produced more estradiol $(p<0.05)$ than did cells treated with FSH alone. Each bar is the mean \pm SE of four determinations. Each well contained 200,000 cells and $1 \mathrm{~mL}$ of medium. This experiment was replicated three times. 
$\mathrm{ng} / \mathrm{mL} \mathrm{LH}$ or $10 \mathrm{ng} / \mathrm{mL} \mathrm{FSH} \mathrm{was} \mathrm{not} \mathrm{statistically} \mathrm{significant}$ presumably because of the lingering effects of FCS constituents present in the preceding $24 \mathrm{~h}$. The medium content of estradiol declined significantly between 24 and $48 \mathrm{~h}$ and was virtually unmeasureable at $96 \mathrm{~h}$ for cells treated with control vehicle or $500 \mu \mathrm{g} / \mathrm{L} \mathrm{GH}$. Addition of $\mathrm{LH}$ to the medium maintained the estradiol content in the medium at greater concentrations than occurred in the absence of LH, but the combination of $\mathrm{LH}$ and $\mathrm{GH}$ was no more effective than $\mathrm{LH}$ alone. FSH also maintained greater concentrations of estradiol in the medium at 48 and at $72 \mathrm{~h}$ compared with control values. Cells treated with a combination of $\mathrm{GH}$ and $\mathrm{FSH}$ averaged $83 \%$ more estradiol in the medium than did cells treated with FSH alone. This finding has been replicated in two additional experiments, but when basal estradiol concentrations have been 2-3-fold greater than in the experiment shown in Figure 3, the augmentation of estradiol accumulation in the medium by the combination of $\mathrm{GH}$ and FSH compared with FSH alone was first seen at $72 \mathrm{~h}$ rather than at $48 \mathrm{~h}$ (data not shown). In one experiment, there was no augmentation of the combination of $\mathrm{GH}$ and FSH. In no experiment has there been significant stimulation or suppression of estradiol accumulation by $\mathrm{GH}$ alone at any concentration (from 0.1 to $1000 \mu \mathrm{g} / \mathrm{L}$ ).

The ability of IGF-I to stimulate the accumulation of estradiol in the medium of luteinized granulosa cells was also determined. Cells were incubated after $24 \mathrm{~h}$ in Ham's F-10 medium containing $10 \%$ FCS. The medium was replaced with Sertoli cell medium containing $500 \mu \mathrm{g} / \mathrm{L} \mathrm{GH}$ or $10 \mathrm{ng} / \mathrm{mL} \mathrm{FSH}$ with or without $100 \mathrm{ng} / \mathrm{mL}$ IGF-I. Medium was removed daily and replaced with fresh medium and hormones. After $24 \mathrm{~h}$ of incubation there was no difference in estradiol concentration in the cells with any hormone treatment (data not shown). In contrast to the results seen with $\mathrm{GH}$, at $48 \mathrm{~h}$ IGF-I produced a 5.6-fold of estradiol accumulation in the medium compared with untreated cells (Fig. 4). The combination of IGF-I and FSH produced a 2.9-fold increase in estradiol accumulation compared with FSH alone. IGF-I and GH in combination were no more effective than IGF-I alone (Fig. 4).

\section{DISCUSSION}

The mechanisms by which $\mathrm{GH}$ produces its action in target tissues are incompletely understood. The growth-promoting

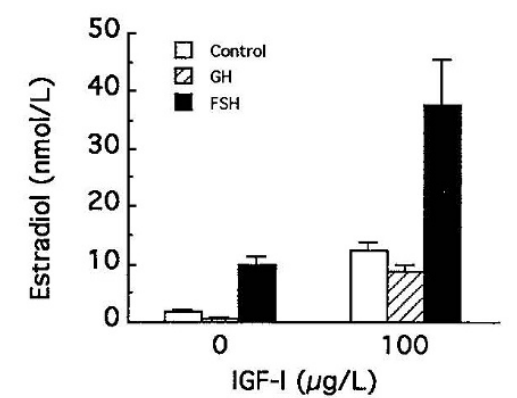

Figure 4. Effect of IGF-I, GH, and FSH on estradiol production. Cells were cultured as described in Figure 3 with control vehicle, the indicated concentration of IGF-I, and $500 \mu \mathrm{g} / \mathrm{L} \mathrm{GH}$ or $10 \mathrm{ng} / \mathrm{mL}$ FSH. The $48-\mathrm{h}$ time point is shown. IGF-I stimulated estradiol production $(p<0.05)$, and the combination of IGF-I and FSH was more effective than either IGF-I or FSH alone ( $p<$ 0.01). This experiment was replicated once. actions of GH appear to be produced via stimulation of production of IGF-I either locally or in peripheral tissues such as liver with subsequent circulation to target sites $(13,14)$. The metabolic actions of GH are opposite to those of IGF-I and are likely to be produced independently of IGF-I (15). The mechanisms by which $\mathrm{GH}$ produces cell differentiation, as in 3T3F442A cells, are not known, but probably involve the regulation of early transcription factors (16). Thus GH effects in granulosa cells potentially could be produced by an independent effect of GH on cell transcription or may be produced by increasing plasma or local concentrations of IGF-I which then increase steroidogenesis and augment gonadotropin action.

In animal studies, $\mathrm{GH}$ appears to produce an increase in steroidogenesis and cell differentiation in granulosa cells (9, $10,17,18)$. However, many of the species studied have local intra-ovarian systems which produce IGF-I as has been demonstrated in rabbit and rat models $(7,19)$. It has been shown recently that, unlike in animals, human granulosa cells do not express mRNA for IGF-I (20). Therefore, if GH produces direct effects in human granulosa cells, the effects are likely to be governed by direct actions of GH rather than via an IGF-I intermediary.

The results of the present experiments indicate that $\mathrm{GH}$, alone, does not increase estradiol or progesterone synthesis in luteinized granulosa cells. IGF-I, in contrast, produces a brisk increase in estradiol production, as others have found (7). The increase in estradiol production is likely to occur in response to induction of aromatase as described by Christman et al. (21).

Our results contrast with those of Barreca et al. (22), who have suggested that $\mathrm{GH}$ alone can augment granulosa cell estradiol production. The cells used in that report were from women undergoing similar in vitro fertilization procedures as in our report, but the luteinized granulosa cells were not subjected to Ficoll separation. Because the $\mathrm{GH}$ effects on estradiol production observed in the study of Barreca et al. could be abolished by antibodies that prevent IGF-I receptor interaction, it is possible that our Ficoll separation step removed cells that made locally available IGF-I in the ovary. IGF-I production in response to $\mathrm{GH}$ administration in these cells could have increased the estradiol production observed in the study of Barreca et al. This is particularly likely in view of the observation that human granulosa cells do not express mRNA for IGF-I (20).

In our study and in the study by Carlsson et al. (8), the combination of $\mathrm{GH}$ and FSH increases estradiol production more than does FSH alone. Even though the results observed in our study were inconsistent, the combination of our data with other reports suggests that $\mathrm{GH}$ could play a modest role in enhancing FSH action in granulosa cells. The GH effect has been modest and seen in only carefully controlled conditions compared with the robust estradiol response to IGF-I. Thus, it seems likely that, in vivo, $\mathrm{GH}$ produces its effects on ovarian granulosa cell steroidogenesis indirectly by increasing circulating IGF-I. Alternatively, GH might increase local IGF-I production from cells in the ovary other than granulosa cells.

There are suggestions that granulosa cells from follicles obtained during surgical oophorectomy or during natural cycle oocyte retrieval may be more responsive to $\mathrm{GH}$ than are cells 
obtained from women undergoing exogenous gonadotropin administration $(8,23)$. This seems unlikely in that the cells retrieved in our study exhibit similar magnitude of $\mathrm{GH}$ response with FSH as seen in other studies. It is also possible that prepubertal ovarian cells might respond to $\mathrm{GH}$ with more differentiation than can be observed in the relatively more differentiated cells obtained during in vitro fertilization. Although this possibility cannot be excluded, we have not observed a $\mathrm{GH}$-induced increase in gonadotropin sensitivity, when we have had the opportunity to examine cells from prepubertal girls (our unpublished observations).

Our studies have concentrated on GH and IGF-I effects on ovarian steroidogenesis. GH may have other effects on ovarian cells. Fore example, GH may increase IGFBP-3 concentrations either through local or systemic effects. IGFBP-3 production in the circulation is controlled in large part, by GH (24). IGFBP-3 has anti-gonadotropin-like activities and may thereby have a role in control of ovarian steroidogenesis (25).

Our studies indicate that IGF-I alone can stimulate estradiol production by human luteinized granulosa cells whereas $\mathrm{GH}$ alone is ineffective. The combination of IGF-I and FSH is much more effective in stimulation of estradiol production than is the combination of $\mathrm{GH}$ and FSH. It therefore seems likely that the predominant mechanism by which $\mathrm{GH}$ augments gonadotropin action in the human ovary is by peripheral expression of IGF-I in such tissues as liver followed by circulatory transfer of IGF-I to the ovary where it subsequently augments gonadotropin action. We speculate that the role that $\mathrm{GH}$ plays in augmenting pubertal development is mediated by IGF-I action rather than by direct effects of $\mathrm{GH}$ at the level of the human ovary.

Acknowledgments. The authors acknowledge the expert technical assistance of Maria Borondy and Katherine Kersey and the secretarial assistance of Teresa Brown and Brigid Kowalczyk.

\section{REFERENCES}

1. Sheikholislam BM, Stempfel Jr RS 1972 Heredity of isolated somatotropin deficiency: effects of human GH administration. Pediatrics 49:362-374

2. Homburg R, Eshel A, Abdalla HI, Jacobs HS 1988 Growth hormone facilitates ovulation induction by gonadotropins. Clin Endocrinol (Oxf) 29:113-117

3. Blumenfeld Z, Lunenfeld B 1989 The potentiating effect of growth hormone on follicle stimulation with human menopausal gonadotropin in a panhypopituitary patient. Fertil Steril 52:328-331

4. Owen EJ, Shoham Z, Mason BA, Ostergaard H, Jacobs HS 1991 Cotreatment with growth hormone, after pituitary suppression, for ovarian stimulation in in vitro fertilization: a randomized, double-blind, placebo-controlled trial. Fertil Steril $56: 1104-1110$
5. Kulin HE, Samojlik E, Santen R, Santner S 1981 The effect of growth hormone on the Leydig cell response to chorionic gonadotropin in boys with hypopituitarism. Clin Endocrinol 15:463-472

6. Copeland KC, Underwood LE, Van Wyk JJ 1980 Induction of immunoreactive somatomedin $\mathrm{C}$ in human serum by growth hormone: dose-response relationships and effect on chromatographic profiles. J Clin Endocrinol Metab 50:690-697

7. Adashi EY, Resnick CE, D'Ercole J, Svoboda ME, Van Wyk JJ 1985 Insulin-like growth factors as intraovarian regulators of granulosa cell growth and function. Endocr Rev 6:400-420

8. Carlsson B, Bergh C, Bentham J, Olsson J-H, Norman MR, Billig H, Roos P, Hillensjo T 1992 Expression of functional growth hormone receptors in human granulosa cells. Hum Reprod 7:1205-1209

9. Jia X-C, Kalmijn J, Hseuh AJ 1986 Growth hormone enhances follicle-stimulating hormone-induced differentiation of cultured rat granulosa cells. Endocrinology 118:1401-1409

10. Yoshimura Y, Nakamura Y, Koyama N, Iwashitan M, Adachit T, Takeda Y 1993 Effects of growth hormone on follicular growth, oocyte maturation and ovarian steroidogenesis. Fertil Steril 59:917-923

11. Padmanabhan V, Chappel SC, Beitins IZ 1987 An improved in vitro bioassay for follicle-stimulating hormone (FSH): suitable for measurement of FSH in unextracted human serum. Endocrinology 121:1089-1098

12. England BG, Niswender GD, Midgley AR 1974 Radioimmunoassay of estradiol-17 $\beta$ without chromatography. J Clin Endocrinol Metab 38:42-50

13. D'Ercole AJ, Stiles AD, Underwood LE 1984 Tissue concentrations of somatomedin-C: further evidence for multiple sites of synthesis and paracrine or autocrine mechanisms of action. Proc Natl Acad Sci USA 81:935-939

14. Daughaday WH, Hall K, Raben MS, Salmon Jr WD, Van Den Brande JL, Van Wyk JJ 1972 Somatomedin: proposed designation for sulphation factor. Nature 235:107

15. Schwartz J, Foster CM, Satin MS 1985 Growth hormone and insulin-like growth factors I and II produce distinct alterations in glucose metabolism in 3T3-F442A adipocytes. Proc Natl Acad Sci USA 82:8784-8728

16. Gurland G, Ashcom G, Cochran BH, Schwartz J 1990 Rapid events in growth hormone action. Induction of c-fos and c-jun transcription in 3T3-F442A preadipocytes. Endocrinology 127:3187-3195

17. Yoshimura $\mathrm{Y}$, Iwahita $\mathrm{M}$, Karube $\mathrm{M}$, Oda $\mathrm{T}$, Akiba $\mathrm{M}$, Shiokawa $\mathrm{S}$, Ando $\mathrm{M}$, Yoshinaga A, Nakamura Y 1994 Growth hormone stimulates follicular development by stimulation ovarian production of insulin-like growth factor-I. Endocrinology 135:887-894

18. Hsu CJ, Hammond JM 1987 Concomitant effects of growth hormone on secretion of insulin-like growth factor I and progesterone by cultured procine granulosa cells. Endocrinology 121:1343-1348

19. Adashi EY, Resnick CE, Hernandez ER, May JV, Knecht M, Svoboda ME Van Wyk JJ 1988 Insulin-like growth factor-I as an amplifier of follicle-stimulating hormone action: studies on mechanism(s) and site(s) of action in cultured rat granulosa cells. Endocrinology 122:1583-1591

20. El-Roeiy A, Chen X, Roberts VJ, LeRoith D, Roberts Jr CT, Yen SSC 1993 Expression of insulin-like growth factor-I (IGF-I) and IGF-II and the IGF-I, IGF-II, and insulin receptor genes and localization of the gene products in the human ovary. J Clin Endocrinol Metab 77:1411-1418

21. Christman GM, Randolph Jr JF, Peegel H, Menon KM 1991 Differential responsiveness of luteinized granulosa cells to gonadotropins and insulin-like growth factor-I for induction of aromatase activity. Fertil Steril 55:1099-1105

22. Barreca A, Artini PG, Del Monte P, Ponzani P, Pasquini P, Cariola G, Vople A Genazzani AR, Giordano G, Minuto F 1993 In vivo and in vitro effect of growth hormone on estradiol secretion by human granulosa cells. J Clin Endocrinol Metab 77:61-67

23. Bergh C, Carlsson B, Olsson J-H, Billig H, Hillensjo T 1991 Effects of insulin-like growth factor $\mathrm{I}$ and growth hormone in cultured human granulosa cells. Ann NY Acad Sci 626:169-175

24. Blum WF, Albertsson-Wikland K, Rosberg S, Ranke MB 1993 Serum levels of insulin-like growth factor (IGF-I) and IGF-binding protein 3 reflect spontaneous growth hormone secretion. J Clin Endocrinol Metab 76:1610-1616

25. Bicsak TA, Shimonaka M, Malkowski M, Ling N 1990 Insulin-like growth factorbinding protein (IGF-BP) inhibition of granulosa cell function: effect on cyclic adenosine $3^{\prime}, 5^{\prime}$-monophosphate, deoxyribonucleic acid synthesis, and comparison with the effect of an IGF-I antibody. Endocrinology 126:2184-2189 